\title{
PENERAPAN MODEL PEMBELAJARAN ICARE UNTUK MENINGKATKAN AKTIVITAS DAN HASIL BELAJAR SISWA (Studi Kasus Pada Siswa Kelas X AK 2 SMK Al Qodiri Jember Mata Pelajaran Akuntansi Kompetensi Dasar Posting Semester Genap Tahun Ajaran 2018/2019)
}

\author{
Nilam Mazidah ${ }^{1}$, Titin Kartini ${ }^{1}$, Sri Kantun ${ }^{1}$ \\ Pendidikan Ekonomi, Fakultas Keguruan dan Ilmu Pendidikan, Universitas Jember \\ Email: mazidahneelam@gmail.com
}

\begin{abstract}
Abstrak
Penelitian ini bertujuan untuk mendeskripsikan penerapan model pembelajaran ICARE dan untuk mengetahui peningkatan aktivitas dan hasil belajar siswa kelas X AK 2 SMK Al Qodiri Jember pada mata pelajaran akuntansi kompetensi dasar posting semester genap tahun ajaran 2018/2019. Penelitian ini merupakan penelitian tindakan kelas yang dilakukan dengan beberapa tahap mulai dari perencanaan, pelaksanaan tindak, observasi, dan refleksi. Subjek penelitian berjumlah 30 siswa pada kelas X AK 2 SMK Al Qodiri Jember. Metode pengumpulan data menggunakan metode observasi, tes, wawancara, dan dokumentasi. Analisis data yang digunakan secara deskriptif dengan pendekatan kualitatif. Hasil penelitian menunjukkan dengan diterapkannya model pembelajaran ICARE dapat meningkatkan aktivitas dan hasil belajar siswa. pada siklus I aktivitas siswa dalam kategori sedang dengan skor 2,5 meningkat pada siklus II menjadi kategori tinggi dengan skor 3,1. Hasil belajar siswa juga mengalami peningkatan, pada siklus I nilai rata-rata yang diperoleh siswa 76,9 dengan ketuntasan belajar secara klasikal 76,6\% meningkat pada siklus II menjadi 83,3 dengan ketuntasan belajar secara klasikal $86,6 \%$.
\end{abstract}

Kata Kunci : Model Pembelajaran ICARE, Aktivitas Belajar, Hasil Belajar, Mata Pelajaran Akuntansi.

\section{PENDAHULUAN}

Proses pembelajaran saat ini tidak hanya melibatkan guru yang berperan aktif dalam kegiatan pembelajaran, akan tetapi siswa juga harus diikutsertakan di dalamnya, karena berhasil tidaknya siswa dalam menyerap suatu materi pembelajaran yang sedang berlangsung tergantung dari proses pembelajarannya. Pembelajaran yang baik yaitu pembelajaran yang mampu melibatkan siswa secara aktif dalam kegiatan pembelajaran di dalam kelas. Hal itu, sesuai dalam kurikulum 2013 yaitu pembelajaran yang berpusat pada siswa. Oleh karena itu, dalam proses pembelajaran dibutuhkan interaksi antara guru dan siswa sehingga dapat menciptakan aktivitas belajar yang baik.

Aktivitas belajar merupakan hal yang penting dalam proses pembelajaran, karena dapat menyediakan kesempatan kepada siswa untuk belajar sendiri secara aktif. Menurut Hamalik (2009:179), aktivitas belajar merupakan kegiatan yang dilakukan oleh siswa dalam kegiatan pembelajaran. Aktivitas belajar meliputi keaktifan siswa dalam mengikuti pelajaran, seperti bertanya hal yang belum jelas, mencatat hal-hal penting materi pelajaran, mendengarkan penjelasan guru, berpikir tentang materi pelajaran, membaca materi pelajaran dan segala kegiatan yang berkaitan dengan materi pelajaran (Sardiman, 2012:95).

Berdasarkan hasil observasi yang telah dilakukan peneliti di kelas X Akuntansi SMK Al Qodiri Jember pada kompetensi dasar sebelumnya yaitu buku jurnal bahwa aktivitas belajar siswa masih rendah. Selama proses pembelajaran siswa hanya diam saja tanpa mengajukan pertanyaan, hal tersebut dianggap bahwa siswa telah memahami materi pelajaran, namun saat guru memberikan pertanyaan kepada siswa, mereka tampak kebingungan untuk menjawab. Terdapat pula beberapa siswa yang tidak dapat mencatat hal-hal penting dari materi pelajaran, mereka hanya berbicara sendiri tanpa mendengarkan penjelasan guru. Bahkan pada saat kegiatan diskusi siswa tidak dapat bertukar pendapat dengan teman kelompoknya. Dengan demikian, dapat dikatakan bahwa aktivitas belajar siswa rendah yang akan berdampak pada hasil belajar. 
Hasil belajar merupakan bagian terpenting dalam kegiatan pembelajaran karena hasil belajaran dijadikan sebagai tolok ukur dalam keberhasilan proses pembelajaran, yang mana dalam tujuan pembelajaran siswa harus mampu mencapai target yang ditentukan. Menurut Supardi (2015:5), pencapaian hasil belajar siswa harus memenuhi kriteria ketuntasan minimal (KKM) yang telah ditentukan. Berdasarkan dokumen yang diperoleh dari guru akuntansi di SMK Al Qodiri Jember pada kelas X Akuntansi hasil belajar siswa pada kompetensi dasar sebelumnya tergolong rendah. Hal tersebut dapat dilihat dari hasil ulangan siswa yang belum mencapai kriteria ketuntasan minimal (KKM) yang telah ditentukan yaitu $\geq 75$ dan ketuntasan klasikal $\geq 75 \%$ dari jumlah siswa yang mencapai KKM. Hasil belajar siswa kelas X AK 1 SMK Al Qodiri Jember menunjukkan nilai ratarata siswa sebesar 76,1 dengan siswa tuntas 25 dan 5 siswa tidak tuntas dengan ketuntasan belajar klasikan sebesar 83,3\% 30 siswa. Sedangkan hasil belajar siswa kelas X AK 2 SMK Al Qodiri Jember memperoleh nilai rata-rata siswa sebesar 70,6 dengan ketuntasan secara klasikal sebesar 46,6\% dari 30 siswa. Dapat disimpulkan bahwa hasil belajar siswa kelas X AK 2 lebih rendah dari kels X AK 1.

Salah satu kompetensi dasar (KD) dalam mata pelajaran akuntansi sesuai dengan silabus SMK Al Qodiri Jember yaitu menerapkan posting. Menurut Jusup H, (2014: 130) proses memindahkan ayat-ayat jurnal yang telah dibuat dalam buku jurnal ke buku besar disebut posting, yaitu memindahkan angka-angka yang tercantum dalam kolom debet jurnal ke dalam sisi debet suatu akun dan memindahkan angka yang tercantum dalam kolom kredit jurnal ke dalam sisi kredit akun yang lain.

Salah satu upaya untuk meningkatkan aktivitas dan hasil belajar siswa pada kompetensi dasar posting yaitu dengan menerapkan model pembelajaran ICARE. Pada proses pembelajaran dengan menerapkan model ICARE harus dilakukan dengan tahapan-tahapan, ini bertujuan untuk mempermudah siswa dalam memahami konsep-konsep perhitungan dari materi yang di ajarkan. Seperti yang diungkapkan Majid (2014: 261) bahwa penerapan model ICARE untuk memastikan bahwa siswa memiliki kesempatan untuk mengaplikasikan, menerapkan pengetahuannya serta kecakapannya. Model pembelajaran ICARE ini juga memberikan kesempatan bagi siswa untuk dapat memindahkan akun-akun yang terdapat pada buku jurnal dengan cara mengubungkan dan mengaplikasikan akun tersebut ke dalam buku besar. Dengan demikian, pada kompetensi dasar posting menerapkan model ICARE peserta didik dapat lebih aktif.

Berdasarkan penjelasan di atas, penelitian ini bertujuan untuk mendeskripsikan penerapan model pembelajaran ICARE dalam meningkatkan aktivitas dan hasil belajar siswa serta untuk mengetahui adanya peningkatan pada aktivitas dan hasil belajar siswa kelas X AK 2 SMK Al Qodiri Jember kompetensi dasar posting semester genap tahun ajaran 2018/2019.

\section{METODE}

Penelitian ini merupakan Penelitian Tindakan Kelas (PTK) yang dilaksanakan mulai dari tahap perencanaan, pelaksanaan tindakan, observasi, dan refleksi. Subyek dalam penelitian ini adalah seluruh siswa kelas X Akuntansi 2 SMK Al Qodiri Jember tahun pelajaran 2018/2019 berjumlah 30 siswa. Terdiri dari 10 siswa laki-laki dan 20 siswa perempuan. Metode pengumpulan data yang digunakan adalah obeservasi, tes, wawancara, dan dokumen. Metode analisis data yang digunakan oleh peneliti ini adalah analisis data secara deskriptif dengan pendekatan kualitatif, yaitu data yang diperoleh saat telah melakukan tindakan.

\section{HASIL DAN PEMBAHASAN Hasil Penelitian}

Penelitian ini dilakukan dengan 2 siklus, yaitu siklus I dan siklus II. Pada siklus I, selama pelaksanaan tindakan pada pembelajaran pertemuan pertama dan pertemuan kedua. Guru melakukan kegiatan pembelajaran sesuai dengan rencana pelaksanaan pembelajaran yang telah disusun. Adapun kendala guru dalam pelaksanaan pembelajaran, yaitu pada tahap connection siswa belum bisa menghubungkan materi yang akan dipelajari dengan materi sebelumnya karena guru belum memberikan kesempatan kepada siswa untuk menghubungkan materi yang akan dijelaskan dengan 
materi sebelumnya, tahap application dimana guru membimbing siswa dalam mengerjakan tugas secara kelompok tetapi masih ada beberapa siswa yang tidak berdiskusi dengan teman kelompoknya dan pada tahap reflection hanya beberapa yang memberikan tanggapannya kepada kelompok lain.

Proses pembelajaran pada siklus I berjalan dengan baik walaupun masih terdapat beberapa kendala yaitu aktivitas siswa pada pertemuan pertama dan terdapat beberapa siswa yang merasa kesulitan dalam memindahkan bukuan dari jurnal ke dalam buku besar, sedangkan pada pertemuan kedua siswa tidak dapat memberikan tanggapan teman saat berdiskusi dengan teman kelompoknya maupun saat kelompok lain presentasi. Berikut ini hasil observasi berupa skor aktivitas belajar siswa pada siklus I, yaitu :

Tabel 1. Skor Aktivitas Belajar Siswa pada Siklus I

\begin{tabular}{clcc}
\hline No & \multicolumn{1}{c}{ Indikator } & $\begin{array}{c}\text { Skor rata- } \\
\text { rata }\end{array}$ & Kategori \\
\hline 1 & Siswa membaca materi posting & 2,3 & Sedang \\
\hline & $\begin{array}{l}\text { Siswa menyimak penejelasan dari guru tentang } \\
\text { posting }\end{array}$ & 3,1 & Tinggi \\
\hline 3 & Siswa berdiskusi tentang posting ke buku besar & 2,3 & sedang \\
\hline & $\begin{array}{l}\text { Siswa bertanya mengenai posting pada guru dan } \\
\text { teman }\end{array}$ & 3 & tinggi \\
\hline 5 & Siswa membuat catatan tentang posting & 2,3 & sedang \\
\hline & $\begin{array}{l}\text { Siswa menanggapi pendapat teman dan guru } \\
\text { mengenai posting }\end{array}$ & 2,3 & sedang \\
\hline & $\begin{array}{l}\text { Siswa bersemangat dalam mengikuti pelajaran } \\
\text { akuntansi KD posting }\end{array}$ & 2,4 & sedang \\
\hline & Rata-rata aktivitas belajar siswa siklus I & $\mathbf{2 , 5}$ & sedang \\
\hline
\end{tabular}

Sumber : Data primer yang diolah, 2019

Tabel di atas menunjukkan bahwa rata-rata aktivitas belajar siswa dalam kategori sedang. Pada siklus I indikator aktivitas belajar siswa skor rata-rata pertemuan I mencapai 2,4 dan pada pertemuan II dengan skor rata-rata 2,6 sehingga dapat disimpulkan skor rata-rata pada siklus I sebesar 2,5 pada kategori sedang.

Aktivitas belajar pada siklus I dengan kategori sedang ini juga berdampak terhadap hasil belajar siswa. Hasil belajar siswa ini diperoleh dari nilai tugas studi kasus dan ulangan harian siswa pada komptensi dasar posting sehingga dapat menentukan nilai rata-rata hasil belajar siswa. Hasil belajar siswa yang diperoleh pada siklus I dapat dilihat pada tabel berikut ini :

\begin{tabular}{cccccc} 
Kelas & $\begin{array}{c}\text { Jumlah } \\
\text { Siswa }\end{array}$ & $\begin{array}{c}\text { Nilai } \\
\text { rata-rata }\end{array}$ & $\begin{array}{c}\text { Jumlah Siswa } \\
\text { yang Tuntas }\end{array}$ & $\begin{array}{c}\text { Jumlah Siswa } \\
\text { yang Tidak } \\
\text { Tuntas }\end{array}$ & $\begin{array}{c}\text { Ketuntasan } \\
\text { Klasikal }\end{array}$ \\
\hline X Ak 2 & 30 & 76,9 & 23 & 7 & $76,6 \%$ \\
\hline
\end{tabular}

Sumber : Data primer yang diolah, 2019

Berdasarkan tabel diatas, dapat dilihat bahwa nilai rata-rata siswa 76,9 dan ketuntasan klasikal belajar secara klasikal sebesar 76,6\%. Ketuntasan klasikal pada siklus I sudah memenuhi KKM yaitu $\geq 75 \%$, namun hal tersebut menjadi pertimbangan untuk melanjutkan pada siklus II sebagai pemantapan dari siklus I.

Aktivitas belajar siswa pada siklus II meningkat dan termasuk dalam kategori tinggi. Adapun hasil observasi berupa skor aktivitas belajar siswa pada siklus II :

Tabel 3. Skor Aktivitas Belajar Siswa pada Siklus II

\begin{tabular}{cccc}
\hline No & Indikator & $\begin{array}{c}\text { Skor rata- } \\
\text { rata }\end{array}$ & Kategori \\
\hline 1 & Siswa membaca materi posting & 3,1 & Tinggi \\
\hline
\end{tabular}




\begin{tabular}{clcc}
\hline & Siswa berdiskusi tentang posting ke dalam buku & 3,1 & Tinggi \\
\hline 3 & besar & 3,2 & Tinggi \\
\hline 4 & $\begin{array}{l}\text { Siswa bertanya mengenai posting pada guru dan } \\
\text { teman }\end{array}$ & 3,1 & Tinggi \\
\hline 5 & Siswa membuat catatan tentang posting & 2,8 & Sedang \\
\hline 6 & $\begin{array}{l}\text { Siswa menanggapi pendapat teman dan guru } \\
\text { mengenai posting }\end{array}$ & 3,2 & Tinggi \\
\hline 7 & $\begin{array}{l}\text { Siswa bersemangat dalam mengikuti pelajaran } \\
\text { akuntansi KD posting }\end{array}$ & $\mathbf{3 , 1}$ & Tinggi \\
\hline
\end{tabular}

Sumber : Data primer yang diolah, 2019

Tabel di atas menunjukkan bahwa rata-rata aktivitas belajar siswa dalam kategori tinggi dengan skor rata-rata 3,1. Skor rata-rata aktivitas belajar siswa pada setiap indikator termasuk pada kategori tinggi meskipun terdapat satu indikator pada kategori sedang, yaitu pada indikator saat siswa menanggapi pendapat teman dan guru mengenai posting hanya mencapai skor 2,8 dengan kategori sedang, hal tersebut dikarenakan guru masih belum bisa memberikan kesempatan kepada siswa untuk mengungkapkan pendapatnya mengenai materi posting. Pada siklus II dapat disimpulkan bahwa pembelajaran dengan menerpakan model ICARE dapat meningkatkan aktivitas belajar siswa kelas X AK 2.

Aktivitas belajar pada siklus II dengan kategori tinggi ini juga berdampak terhadap hasil belajar siswa, yang diperoleh dari tugas studi kasus dan ulangan harian siswa pada kompetensi dasar posting sehingga dapat menentukan nilai rata-rata dari hasil belajar siswa. Hasil belajar siswa yang diperoleh pada siklus II dapat dilihat pada tabel berikut ini :

Tabel 4. Hasil Belajar Siswa Pada Siklus II

\begin{tabular}{cccccc}
\hline Kelas & $\begin{array}{c}\text { Jumlah } \\
\text { Siswa }\end{array}$ & $\begin{array}{l}\text { Nilai } \\
\text { rata-rata }\end{array}$ & $\begin{array}{c}\text { Jumlah Siswa } \\
\text { yang Tuntas }\end{array}$ & $\begin{array}{c}\text { Jumlah Siswa } \\
\text { yang Tidak } \\
\text { Tuntas }\end{array}$ & $\begin{array}{c}\text { Ketuntasan } \\
\text { Klasikal }\end{array}$ \\
\hline X Ak 2 & 30 & 83,3 & 26 & 4 & $86,6 \%$ \\
\hline
\end{tabular}

Sumber : Data primer yang diolah, 2019

Berdasarkan tabel di atas, dapat dilihat bahwa nilai rata-rata 83,3 dan ketuntasan belajar secara klasikal sebesar 86,6\%. Hasil tersebut menunjukkan bahwa hasil belajar siswa sudah memenuhi target pembelajaran pada siklus II.

Pemaparan di atas dapat disimpulkan bahwa guru telah melakukan aktivitas sesuai dengan rencana perbaikan pembelajaran dari kekurangan-kekurangan pada pelaksanaan siklus I telah diperbaiki pada siklus II. Guru sudah terbiasa dengan menerapkan model ICARE dalam pembelajaran akuntansi dan tidak mengalami kesulitan lagi, serta guru semakin terbantu dengan adanya model ICARE dalam meningkatkan aktivitas belajar siswa. Selain itu, peningkatan aktivitas belajar juga berdampak terhadap hasil belajar siswa yang dapat mencapai KKM yaitu $\geq 75$ dengan ketuntasan belajar klasikal $\geq 75 \%$.

Peningkatan aktivitas dan hasil belajar siswa yang sudah mencapai target yang telah ditentukan, maka guru dan peneliti memutuskan untuk menghentikan penelitian ini karena tujuan penelitian yang direncanakan sudah tercapai dan juga adanya keterbatasan izin dari pihak sekolah.

Hasil penelitian pada siklus I menunjukkan bahwa aktivitas belajar siswa masih pada kategori sedang dan pada siklus II menunjukkan peningkatan pada setiap indikator aktivitas belajar siswa. Hal itu dapat dilihat dari masing-masing indikator memiliki kategori tinggi dengan adanya model ICARE yang diterapkan di kelas X AK 2 pada mata pelajaran akuntansi kompetensi dasar posting. Peningkatan aktivitas belajar siswa pada siklus I dan siklus II dapat dilihat pada tabel dan diagram berikut ini :

Tabel 4.7 Rekapitulasi Aktivitas Belajar Siswa Kelas X AK 2

\begin{tabular}{llll}
\hline No & Siklus & Skor Rata-rata Aktivitas & Kriteria \\
\hline
\end{tabular}




\begin{tabular}{llcc}
\hline \multicolumn{3}{c}{ Belajar Siswa } \\
\hline 1. & Siklus I & 2,5 & Sedang \\
\hline 2. & Siklus II & 3,1 & Tinggi \\
\hline
\end{tabular}

Sumber : Data primer yang diolah, 2019

Tabel diatas menunjukkan bahwa terjadi peningkatan aktivitas belajar siswa dari siklus I ke siklus II. Aktivitas belajar siswa sebelum tindakan sebesar 1,8 pada siklus I sebesar 2,5 menjadi 3,1 pada siklus II. Pada siklus I aktivitas belajar siswa masih berada pada kategori sedang, oleh karena itu peneliti perlu melakukan siklus II untuk meningkatkan indikator aktivitas belajar siswa. Pada siklus II terjadi peningkatan aktivitas belajar siswa yang tinggi pula.

Peingkatan aktivitas belajar juga berdampak terhadap hasil belajar siswa yang diperoleh dari tugas studi kasus dan ulangan harian sehingga dapat memperoleh nilai akhir dari hasil belajar siswa, hal itu dapat dilihat dari hasil belajar siswa yang diperoleh pada siklus ke siklus II pada tabel berikut :

Tabel 4.8 Rekapitulasi Hasil Belajar Siswa Kelas X AK 2

\begin{tabular}{lcccc}
\hline No & Siklus & Jumlah Siswa & Nilai Rata-rata & Ketuntasan Klasikal \\
\hline 1. & I & 30 & 76,9 & $76,6 \%$ \\
\hline 2. & II & 30 & 83,8 & $86,6 \%$ \\
\hline & Peningkatan & & 6,9 & $10 \%$ \\
\hline
\end{tabular}

Sumber : Data primer yang diolah, 2019

Pada tabel di atas dapat dilihat bahwa terjadi peningkatan pada hasil belajar siswa.

Peningkatan sebesar 6,9 nilai rata-rata siswa dari 76,9 menjadi 83,8. Sedangkan, peningkatan ketuntasan belajar secara klasikal dari siklus I ke siklus II sebesar 76,6\% meningkat sebesar $10 \%$ menjadi $86,6 \%$, peningkatan hasil belajar juga dapat disajikan pada diagram berikut ini :

\section{Hasil Belajar Siswa Pada Siklus I dan Siklus II}

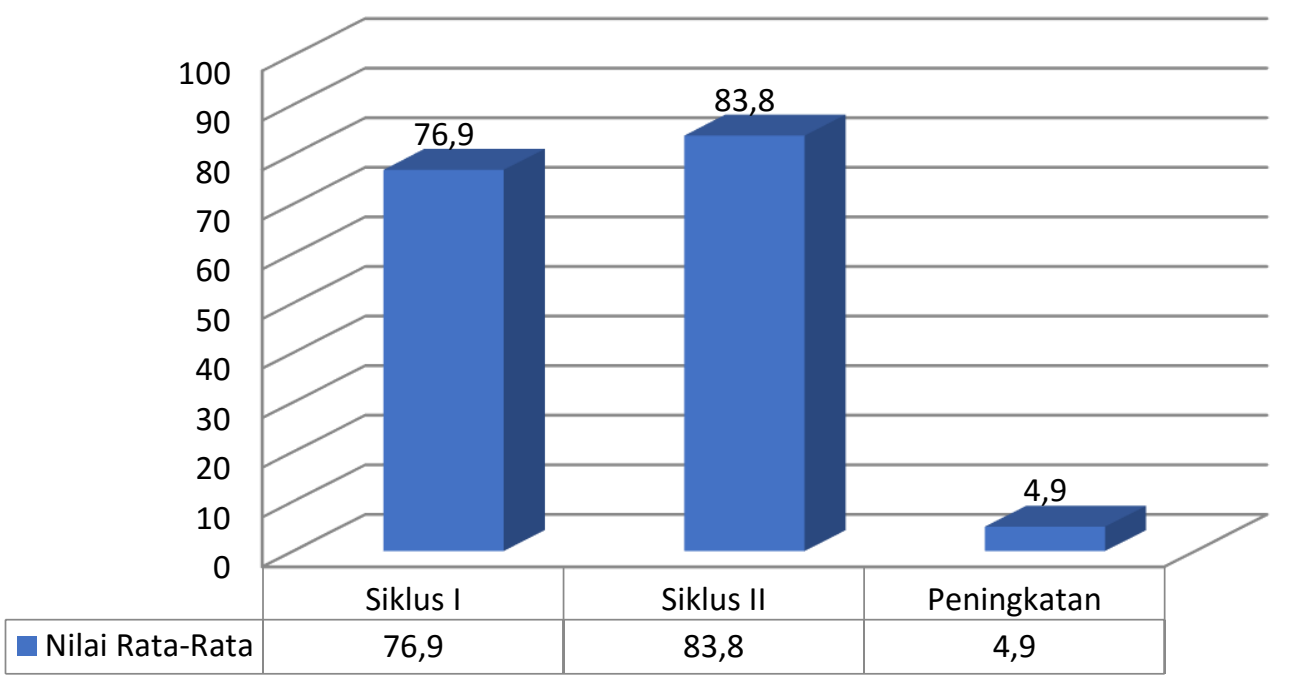

Diagram 4.3 Peningkatan hasil belajar peserta didk dari siklus I ke siklus II

\section{Pembahasan}

Penelitian ini telah dibuktikan bahwa penerapan model ICARE dalam penelitian ini dapat meningkatkan aktivitas dan hasil belajar siswa kelas X AK 2 di SMK Al Qodiri Jember pada mata pelajaran akuntansi kompetensi dasar posting sesuai dengan hipotesis yang diajukan. Berdasarkan hasil penelitian menunjukkan bahwa aktivitas belajar siswa mengalami peningkatan dari siklus I ke siklus II, yaitu dari kategori sedang menjadi kategori tinggi dengan skor aktivitas belajar siswa pada siklus I sebesar 2,5 menjadi 3,2 pada siklus II.

Peningkatan aktivitas belajar siswa tersebut terjadi pada indikator aktivitas belajar siswa membaca materi posting, siswa menyimak penejelasan dari guru tentang posting, siswa berdiskusi tentang posting ke dalam buku besar, siswa bertanya mengenai posting pada guru dan teman, siswa 
membuat catatan tentang posting, siswa menanggapi pendapat teman dan guru mengenai posting, siswa bersemangat dalam mengikuti pelajaran akuntansi kompetensi dasar posting. Pernyataan tersebut menunjukkan bahwa dengan menerapkan model ICARE dapat menjadikan siswa lebih aktif dalam proses pembelajaran pada mata pelajaran akuntansi kompetensi dasar posting. Sesuai dengan pendapat Majid (2014: 261) bahwa penerapan model ICARE dapat memberikan kesempatan kepada siswa untuk mengaplikasikan, menerapkan pengetahuannya serta kecakapannya. Dengan demikian, pada kompetensi dasar posting dengan menerapkan model ICARE siswa dapat lebih aktif. Model ICARE ini juga menjadikan siswa memiliki keterampilan sehingga siswa dapat lebih aktif dalam proses pembelajaran dan dapat meningkatkan aktivitas belajar (Wahyudin, 2010: 29).

Aktivitas belajar siswa yang meningkat berdampak pada hasil belajar siswa. Hasil belajar siswa dilihat dari nilai ulangan harian siswa pada kompetensi dasar posting. Hasil penelitian menunjukkan bahwa hasil belajar siswa mengalami peningkatan pada siklus I nilai rata-rata siswa sebesar 76,9 menjadi 83,8 pada siklus II. Sedangkan, peningkatan ketuntasan belajar secara klasikal dari siklus I ke siklus II sebesar 76,6\% meningkat sebesar $10 \%$ menjadi $86,6 \%$. Seperti yang diungkap oleh Wahyudin (2010: 29) bahwa model ICARE memiliki beberapa kelebihan dibandingkan dengan model lainnya, yaitu guru dan siswa dapat menyeimbangkan antara teori dan penjelasan guru serta praktek langsung yang dilakukan oleh siswa, memberikan kesempatan kepada guru untuk melakukan apersepsi pada setiap pembelajaran yang akan dilakukan dengan mudah sehingga dapat menjadikan siswa lebih memahami tentang materi pelajaran yang diajarkan dan dapat meningkatkan hasil belajar. Hal tersebut diperkuat oleh pernyataan guru akuntansi yang menyatakan bahawa :

“....model pembelajaran ICARE dapat memudahkan saya dan siswa dalam proses pembelajaran. Siswa dapat lebih aktif dalam proses pembelajaran dari pada sebelum diterapkannya model ICARE ini. Langkah-langakah dalam model ini juga menjadikan siswa lebih aktif karena dalam proses pembelajaran siswa sangat bersemangat dalam mengerjakan tugas, karena tugas dapat dikerjakan secara kelompok. Dalam model ini juga siswa dapat menghubungkan materi yang akan dijelaskan dengan materi yang sebelumnya, sehingga dapat memudahkan Siswa dalam memahami materi yang akan diajarkan.” (Bpk. W, 27 Tahun)

Siswa juga mengatakan bahwa model ICARE dapat meningkatkan aktivitas dan hasil belajar mereka. Hal itu diketahui dari pernyataan salah satu siswa yang mengatakan bahwa :

“.... saya sangat senang dengan adanya model ICARE ini karena dapat meningkatkan aktivitas dan hasil belajar. Saya lebih memahami materi pelajaran. Dalam model ini siswa dapat menghubungkan materi sebelumnya dengan materi yang akan dipelajari. Saat diskusi kelompok siswa dapat mengungkapkan pendapatnya dan dapat mengerjakan tugas dengan baik serta siswa dapat menyampaikan hasil diskusi kelompok saat kegiatan presentasi. Pembelajaran dengan model ini sangat menyenangkan yang membuat saya semangat di dalam kelas.” (S, 16 tahun)

Berdasarkan hasil penelitian, dan wawancara dengan guru dan siswa serta dukungan teori maka dapat disimpulkan bahwa penerapan model pembelajaran ICARE dapat meningkatkan aktivitas belajar dan hasil belajar siswa. Hal tersebut dapat dilihat dari antusias siswa dalam mengikuti proses pembelajaran, sehingga model pembelajaran tersebut dapat diterapkan dalam proses pembelajaran mata pelajaran akuntansi kompetensi dasar posting.

\section{PENUTUP}

Berdasarkan hasil penelitian dan pembahasan, dapat disimpulkan bahwa penerapan model ICARE dapat meningkatkan aktivitas dan hasil belajar siswa kelas X AK 2 SMK AL Qodiri Jember pada mata pelajaran akuntansi kompetensi dasar posting tahun ajaran 2018/2019. Peningkatan aktivitas belajar siswa dapat dilihat dari skor rata-rata aktivitas belajar pada siklus I sebesar 2,5 dengan kategori sedang dan siklus II menjadi 3,1 dengan kategori tinggi.

Peningkatan hasil belajar siswa setelah pelaksanaan tindakan pada siklus I dapat dilihat dengan nilai rata-rata 76,9 dan ketuntasan belajar secara klasikal 76,6\%, kemudian meningkat lagi pada siklus II menjadi 83,3 dan ketuntasan belajar secara klasikal 86,6\%.

Berdasarkan hasil penelitian ini, maka peneliti dapat memberikan saran yaitu sebaiknya guru dalam proses pembelajaran menggunakan model pembelajaran yang tepat sesuai dengan karakteristik 
siswa dan materi pelajaran yang diajarkan agar dapat meningkatkan aktivitas dan hasil belajar siswa, salah satunya guru dapat menerapkan model pembelajaran ICARE yang sudah diterapkan pada penelitian ini.

\section{DAFTAR PUSTAKA}

Hamalik, O. 2009. Proses Belajar Mengajar. Jakarta: PT. Bumi Aksara.

Jusup, A. H. 2014. Dasar-Dasar Akuntansi Jilid I. Yogyakarta: Sekolah Tinggi Ilmu Ekonomi YKPN.

Majid, A. 2014. Belajar dan Pembelajaran. Bandung: PT. Remaja Rosdakarya.

Sardiman. 2012. Motivasi Belajar Mengajar. Jakarta: Raja Grafinda Persada. 